\title{
Ürik Asit Obstrüktif Uyku Apne Sendromunda Bir Belirteç midir?
}

\section{Is Uric Acid a Marker in Obstructive Sleep Apnea Syndrome?}

\author{
Elif Torun Parmaksız, Banu Salepçi, Gülten Aktın Güngör, Sevda Cömert, Ergün Parmaksız* \\ Sağlık Bilimleri Üniversitesi, Dr. Lütfi Kırdar Kartal Eğitim ve Araştırma Hastanesi, Göğüs Hastalıkları Kliniği, Istanbul, Türkiye \\ *Sağlık Bilimleri Üniversitesi, Dr. Lütfi Kırdar Kartal Eğitim ve Araştırma Hastanesi, Nefroloji Kliniği, Istanbul, Türkiye
}

\section{Öz}

Amaç: Ürik asit, kardiyovasküler hastalıklar, kronik böbrek yetersizliği, metabolik sendrom gibi durumlarda yükselen güçlü ve bağımsız bir morbidite ve mortalite belirtecidir. Obstrüktif uyku apne sendromu'nda (OUAS) gece boyu meydana gelen hipoksi-arousal-reoksijenasyon siklusları, adenozin trifosfat yıkımına neden olarak pürin metabolizması ürünü olan ürik asit oluşumunu arttırır. Çalışmamızda OUAS ile serum ürik asit düzeyleri arasındaki ilişkiyi değerlendirmeyi amaçladık.

Gereç ve Yöntem: Uyku laboratuvarımızda polisomnografi (PSG) ile değerlendirilen hastalar prospektif olarak değerlendirildi. Tüm hastaların demografik verileri, komorbiditelerini içeren ayrıntılı özgeçmişi, sigara öyküsü kaydedildi. Tüm gece PSG uygulandı, tam kan sayımı ve biyokimya analizleri yapıldı.

Bulgular: Çalışmamıza yaş ortalaması 47,78 (18-65) olan 449 olgu dahil edildi. Çalışma popülasyonu 283 erkek (\%63), 166 kadından (\%37) oluşmaktaydı. PSG verilerine göre 43 hastada apne-hipopne indeksi $<5$ bulundu, 406 olguda OUAS saptandı. Ek hastalıklar değerlendirildiğinde hipertansiyon 135 (\%30), diabetes mellitus 80 (\%18), koroner arter hastalığı 53 (\%12), astım 53 (\%12), dislipidemi 14 (\%3), kronik obstrüktif akciğer hastalığı $12(\% 2,7)$ olguda saptandı. Serum ürik asit düzeyi 75 olguda yüksek bulundu; bu olguların 3'ü kontrol, 72'si OUAS grubunda idi. Hafif OUAS grubunda 13, orta OUAS grubunda 25, ağır OUAS grubunda ise 34 olguda ürik asit düzeyi artmış bulundu. Serum ürik asit düzeyi OUAS grubunda anlamlı olarak daha yüksek bulundu.

Sonuç: Tam kan sayımı verileri ve serum üre düzeyi iki grupta benzer bulunurken, kreatinin düzeyi OUAS olanlarda anlamlı şekilde yüksek bulundu. Serum ürik asit ve kreatinin düzeyleri hastalığın ağırlığı ilerledikçe anlamlı olarak artmaktaydı. Olgularda cinsiyete göre ürik asit düzeyleri karşılaştırıldığında kadınlarda ortalama 5,29 mg/dL, erkeklerde ortalama $6,58 \mathrm{mg} / \mathrm{dL}$ ile bulundu; aradaki fark istatistiksel olarak anlamlıydı.

Anahtar Kelimeler: Obstrüktif uyku apne sendromu, ürik asit, apne hipopne indeksi

\begin{abstract}
Objective: Uric acid which arises in conditions such as cardiovascular diseases, Chronic kidney failure, metabolic syndrome is a strong and independent marker of morbidity and mortality. Hypoxia-arousalreoxygenation cycles that observed in Obstructive sleep apnea syndrome (OSAS) throughout the night increase adenosine triphosphate degradation and cause uric acid production, an end-product of purine metabolism. We aimed to evaluate the relationship between OSAS and serum uric acid levels.

Materials and Methods: Subjects who were evaluated by polysomnography (PSG) in our sleep laboratory were prospectively analysed. Demographic data, detailed history including comorbidities, smoking history of all the patients were recorded. PSG was performed all night and complete blood count and biochemical analysis were done. Results: Total of 449 subjects with a mean age of 47.78 (18-65) were included in the study. The study population consisted of $283(63 \%)$ male and 166 (37\%) female. According to PSG data, 43 subjects had apneahypopnea index was $<5$ and 406 subjects had OSAS. As comorbidities evaluated, hypertension in $135(30 \%)$, diabetes mellitus in $80(18 \%)$, coronary heart disease in $53(12 \%)$, asthma in $53(12 \%)$, dyslipidemia in $14(3 \%)$, chronic obstructive pulmonary disease in $12(2.7 \%)$ patients were found. Serum uric acid level was high in 75 cases; 3 of which was in control group and 72 of which was in OSAS group. Uric acid level was increased in 13 patients with mild OSAS, 25 patients with moderate OSAS and 34 patients with severe OSAS. Serum uric acid level was significantly higher in OSAS group compared to control group.

Conclusion: Complete blood count data and serum urea levels were found similar in both groups, whereas creatinine was significantly higher in OSAS patients. Serum uric acid and creatinine levels were increasing significantly as the disease got more severe. When patient uric acid levels were compared by gender, mean uric acid level was $5.29 \mathrm{mg} / \mathrm{dL}$ in women and $6.58 \mathrm{mg} / \mathrm{dL}$ in men; the difference between genders was statistically significant.

Keywords: Obstructive sleep apnea syndrome, uric acid, apnea hypopnea index
\end{abstract}

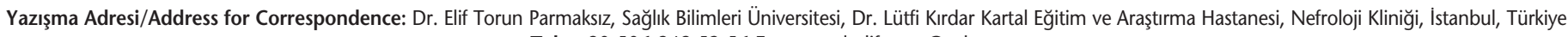
Tel.: +90 5062425356 E-posta: dreliftorun@yahoo.com

Geliş Tarihi/Received: 22.11.2016 Kabul Tarihi/Accepted: 24.01.2017

Bu çalışma, 2016 Türk Uyku Tıbbı Dergisi Kongresi'nde sunulmuştur.

๑Telif Hakkı 2016 Türk Uyku Tıbbı Derneği / Türk Uyku Tıbbı Dergisi, Galenos Yayınevi tarafından basılmıştır. 


\section{Giriş}

Obstrüktif uyku apne sendromu (OUAS), uykuda meydana gelen tekrarlayan üst hava yolu obstrüksiyonu ve buna bağlı gelişen horlama, tekrarlayan apne ve hipopne dönemleri ile karakterize klinik tablodur. Uyku süresince oksijen satürasyonunun düşmesi ve reoksijenasyonun sağlanması döngüsü oksidatif stresi arttırır (1). OUAS'ta gece boyu meydana gelen hipoksiarousal-reoksijenasyon siklusları, adenozin trifosfat yıkımına neden olarak ürik asit oluşumunu arttırabilir. Ürik asit bir oksidatif stres belirteci olarak kabul edilmektedir. Vücutta pürin degredasyonun ürünü olarak oluşur, başlıca üretim yeri karaciğer, atıldığı yerler böbrek ve karaciğerdir. Adenozin monofosfat, inozin monofosfat ve guanozin monofosfattan oluşan pürin mononükleotidlerinin son yıkım ürünüdür. Ürik asit, kardiyovasküler hastalıklar, kronik böbrek yetmezliği, metabolik sendrom gibi durumlarda yükselen güçlü ve bağımsız bir morbidite ve mortalite belirtecidir. Bu klinik durumlarda ürik asitin artış nedeni tam belirlenmemiş olmakla beraber, ürik asitin oksidatif stres, enflamatuvar ve diğer patogenetik mekanizmalar ile ilişkili olduğu düşünülmektedir (2-4). Çalışmamızda OUAS ile serum ürik asit düzeyleri arasındaki ilişkiyi değerlendirmeyi amaçladık.

\section{Gereç ve Yöntem}

Uyku laboratuvarımıza horlama, tanıklı apne, gündüz aşııı uykululuk, tatminsiz uyku gibi şikayetler ile başvuran veya refere edilen ve tüm gece polisomnografi (PSG) ile değerlendirilen hastalar prospektif olarak değerlendirildi. Olgulara işlemler anlatılarak, onam formu imzalatıldı. Tüm hastaların demografik verileri, komorbiditeleri içeren ayrıntılı öz geçmişi, sigara öyküsü kaydedildi. Ayrıntılı fizik muayene yapıldı, boy ve kilo ölçümleri alınarak kaydedildi. Tüm gece PSG uygulandı. Arter kan gazı alındı. Takip eden sabah açlık kanı alınarak tam kan sayımı ve açlık kan şekeri, üre, kreatinin, ürik asit ve lipid düzeylerini içeren biyokimya analizleri yapıldı. Serum ürik asit düzeyi $7,2 \mathrm{mg} /$ dL'nin üzerinde olması ürik asit yüksekliği olarak kabul edildi.

Gece boyunca PSG incelemeyi tolere edemeyerek etkin uyku uyuyamayan olgular, bilinen gut, hiperparatiroidi, böbrek yetmezliği veya nefropatisi, asidozu olanlar, renal transplant olguları, dekompanse kalp yetmezliği olguları ve ürik asit düzeylerini etkileyecek salisilik asit, diüretik, antineoplastik veya antitübeküloz ilaçlar, teofilin, allopurinol ve levodopa kullanan olgular, kronik alkol kullanımı olan veya çalışma günü alkol almış olan olgular çalışmaya dahil edilmedi.

PSG, eğitilmiş teknisyenler tarafından gece boyunca kamera eşliğinde uygulandı. On altı kanallı Viasys Sleep Screen cihazıyla 2 kanal elektroensefalografi (EEG) (C4A1, C3A2), 2 kanal elektrookülografi (O2A1, O1A2), submental, sağ tibia ve sol tibia elektromiyografi derivasyonları kullanılarak poligrafik kayıtlar, horlama sensörü, elektrokardiyografi elektrotları, nazal kanül, toraks ve abdomen kemerleri, pulse oksimetre probu kullanılarak solunumsal ve kardiyak kayıtlar yapıldı. EEG skorlaması Rechtschaffen-Kales (5) skorlama kurallarına göre, solunum skorlaması ise American Academy of Sleep Medicine (AASM) tarafından son olarak 2012 yllında revize edilerek Manual for Scoring Sleep-Version 2'ye (6) göre uyku konusunda deneyimli, sertifikalı uzman hekimler tarafından gerçekleştirildi. Olgular AASM 2012 kriterlerine göre apne hipopne indeksi
(AHI) $<5$ normal, $\mathrm{AHI}=5-15$ hafif şiddette OUAS, $\mathrm{AHI}=16-30$ orta şiddette OUAS, AHI $>30$ ağır şiddette OUAS olarak dört gruba ayrıldı. Olguların vücut kitle indeksleri (VKi), vücut ağırlığı/boy formülüne göre $\mathrm{kg} / \mathrm{m}^{2}$ olarak hesaplandı.

\section{İstatistiksel Analiz}

Istatistiksel analizler için SPSS 17.0 programı kullanıldı. Sıklık dağııımları hesaplandı. Kantitatif veriler için ortalama değerler hesaplandı ve karşılaştırmalar t-testi ve ANOVA ile yapıldı. P değerinin 0,05 'in altında olması istatistiksel olarak anlamlı kabul edildi. Ürik asit düzeylerini etkileyen bağımsız değişkenler regresyon analizleri ile değerlendirildi.

\section{Bulgular}

Çalışmamıza yaş ortalaması 48 (18-65) olan 449 olgu dahil edildi. Çalışma popülasyonu 283 erkek (\%63), 166 kadından (\%37) oluşmaktaydı. PSG verilerine göre 43 hastada $\mathrm{AHI}<5$ bulundu ve kontrol grubu olarak alındı; 406 olguda OUAS saptandı. Bunların 120 'si hafif $(\% 29,5), 124$ 'ü orta (\%30,5), 162'si ağır (\%40) olarak sınıflandıııdı. Kadın/erkek oranı OUAS grubunda 145/262 iken, OUAS olmayan grupta 21/22 idi (Şekil 1).

Ek hastalıklar değerlendirildiğinde 135 (\%30) olguda hipertansiyon, 80 (\%18) olguda diabetes mellitus (DM), 53 (\%12) olguda koroner arter hastalığı (KAH), 53 (\%12), olguda astım, 14 (\%3) olguda dislipidemi, $12(\% 2,7)$ olguda kronik obstrüktif akciğer hastalığı (KOAH) saptandı. Bu komorbiditelerin OUAS olan ve olmayan gruplardaki dağılımı Şekil 2'de gösterilmiştir. Sigara içenler toplam popülasyonun $\% 53$ 'ünü oluşturuyordu; \%22,7'sinde $(n=212) 20$ paket yıldan fazla sigara öyküsü vardı.

Serum ürik asit düzeyi 75 olguda yüksek bulundu; bu olguların 3'ü OUAS olmayan, 72'si OUAS grubunda idi. Hafif OUAS grubunda 13, orta OUAS grubunda 25, ağır OUAS grubunda ise 34 olguda ürik asit düzeyi artmış bulundu. OUAS olan ve olmayan gruplar karşılaştırmalı olarak değerlendirildiğinde yaş ve VKI OUAS olan olgularda istatistiksel olarak anlamlı şekilde yüksek bulundu (sırasıyla $p=0,001$ ve $p<0,0001$ ). Uyku mimarisi değerlendirildiğinde, uyku etkinliği, uyku latansı, hızı göz hareketi (REM) latansı ve REM süresi apneik olan ve olmayan gruplarda benzer bulundu. Serum ürik asit düzeyi OUAS grubunda anlamlı olarak daha yüksek bulundu $(p<0,0001)$. Tam kan sayımı verileri ve serum üre düzeyi iki grupta benzer

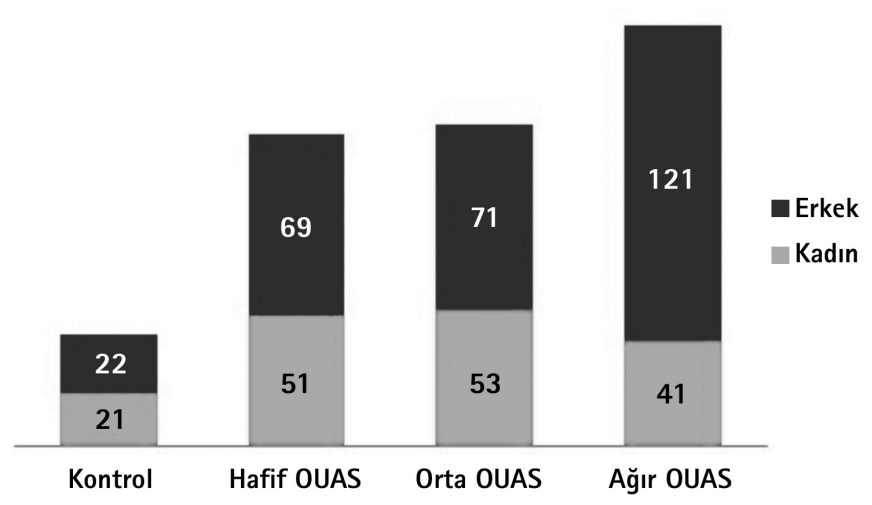

Şekil 1. Hastalığın ağırlığına göre cinsiyet dağılımları OUAS: Obstrüktif uyku apne sendromu 
bulunurken, kreatinin düzeyi OUAS olanlarda anlamlı şekilde yüksek bulundu (Tablo 1).

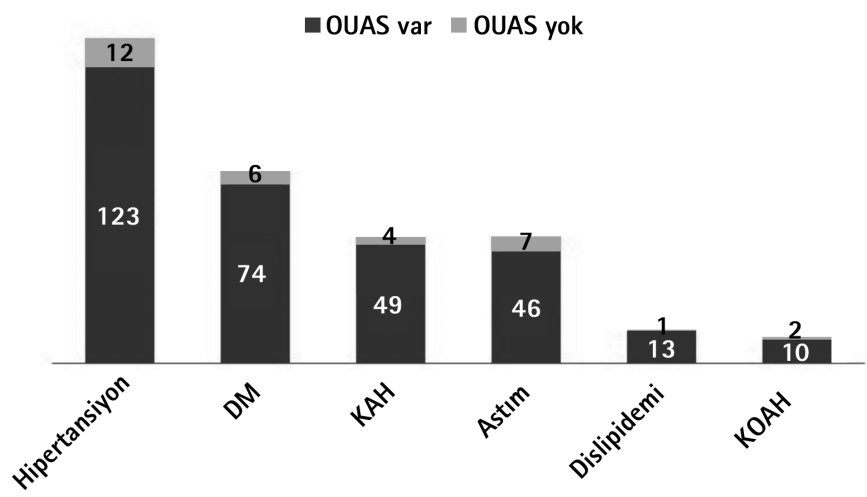

Şekil 2. Komorbiditelerin Obstrüktif uyku apne sendromu olan ve olmayan gruplardaki dağılımı

OUAS: Obstrüktif uyku apne sendromu, DM: Diabetes mellitus, KAH: Koroner arter hastalığı, KOAH: Kronik obstrüktif akciğer hastalığı

Tablo 1. Obstrüktif uyku apne sendromu varlığına göre polisomnografik verilerin ve biyokimyasal belirteçlerin ortalama değerleri

\begin{tabular}{|l|l|l|l|}
\hline & $\begin{array}{l}\text { Kontrol } \\
(\mathbf{n}=43)\end{array}$ & $\begin{array}{l}\text { OUAS } \\
(\mathbf{n}=\mathbf{4 0 6})\end{array}$ & p değeri \\
\hline Yaş & 41,4 & 49,5 & $\mathbf{0 , 0 0 1}$ \\
\hline VKI & 27,7 & 31,7 & $<0,0001$ \\
\hline Uyku süresi (dk.) & 330 & 303 & $\mathbf{0 , 0 4}$ \\
\hline Uyku etkinliği (\%) & 78 & 79 & 0,62 \\
\hline Uyku latansı (dk.) & 23 & 19 & 0,4 \\
\hline REM latansı (dk.) & 135 & 125 & 0,5 \\
\hline Evre 1 (\%) & 5,5 & 7,4 & $\mathbf{0 , 0 0 4}$ \\
\hline Evre 2 (\%) & 58 & 62,5 & $\mathbf{0 , 0 1}$ \\
\hline Evre 3 (\%) & 20 & 15 & $\mathbf{0 , 0 0 2}$ \\
\hline REM (\%) & 16,5 & 14,5 & 0,1 \\
\hline AHI & 2,4 & 32,5 & $<0,0001$ \\
\hline Al & 0,7 & 20 & $<0,0001$ \\
\hline SpO ${ }_{2} \% 90$ altında geçen süre & 4,2 & 17 & $<0,0001$ \\
\hline ODI & 1,9 & 28 & $<0,0001$ \\
\hline Minimum SpO 2 (\%) & 90 & 81 & $<0,0001$ \\
\hline Ortalama SpO 2 (\%) & 95 & 92 & $<0,0001$ \\
\hline Hemoglobin (g/dL) & 13,7 & 13,8 & 0,64 \\
\hline Hematokrit (\%) & 40,9 & 41,3 & 0,6 \\
\hline Lökosit & 7454 & 7788 & 0,3 \\
\hline Trombosit & 246666 & 247264 & 0,9 \\
\hline Ürik asit (mg/dL) & 5 & 6,2 & $<0,0001$ \\
\hline Üre (mg/dL) & 31 & 34 & 0,13 \\
\hline Kreatinin (mg/dL) & 0,77 & 0,84 & 0,02 \\
\hline $\begin{array}{l}\text { OUAS: Obstrüktif uyku apne sendromu, VKI: Vücut kitle indeksleri, REM: Hızl } \\
\text { göz hareketi, AHi: Apne hipopne indeksi, Ai: Apne indeksi ODi: Oksijenasyon } \\
\text { desatürasyon indeksi }\end{array}$ & & & \\
\hline
\end{tabular}

OUAS olguları PSG verilerine göre hafif, orta, ağır olarak sınıflandırıldığında yaş ve VKİ gruplar arasında istatistiksel olarak farklı bulundu $(p<0,0001)$. Uyku etkinliği, uyku latansı, REM latansı benzer bulunurken, hastalığın ağırlığı arttıkça evre 1 ve 2 süresinin arttığı, evre 3 ve REM sürelerinin azaldığı gözlendi. Serum ürik asit ve kreatinin düzeyleri hastalığın ağırlığı ilerledikçe anlamlı olarak artmaktaydı. Hipertansiyon, DM, dislipidemi, $\mathrm{KOAH}$, astım ve $\mathrm{KAH}$ olan ve olmayan gruplar arasında ortalama ürik asit düzeyleri açısından anlamlı fark bulunmadı (sırasıyla $\mathrm{p}=0,74 ; 0,54 ; 0,82 ; 0,45 ; 0,13 ; 0,24$ ) (Tablo 2).

Tüm yaş grupları dahil edilerek, cinsiyete göre ürik asit düzeyleri karşılaştırıldığında kadınlarda ortalama 5,29 mg/dL, erkeklerde ortalama $6,58 \mathrm{mg} / \mathrm{dL}$ ile bulundu; aradaki fark istatistiksel olarak anlamlıydı $(p<0,0001)$. Kadın hastalar premenapozal ve postmenapozal olarak iki gruba ayrıldığında premenapozal grupta ürik asit ortalaması 5,2 mg/dL; postmenapozal grupta $6,5 \mathrm{mg} / \mathrm{dL}$ bulundu.

Ürik asit seviyeleri normal ve yüksek olan gruplar karşılaştırıldığında, VKi her iki grupta benzer bulundu (sırasıyla 3,09 ve 31,$75 ; p=0,32$ ). Hiperürisemik grupta $A H I$, oksijenasyon desatürasyon indeksi (ODi) ve $\mathrm{O}_{2}$ satürasyonunun \%90'ın altında ölçüldüğü süreler daha yüksek (sırasıyla p=0,04, 0,019, 0,005); minimum $\mathrm{O}_{2}$ satürasyonu ve ortalama satürasyonu daha düşük (sırasıyla $p=0,014,0,01$ ) bulundu (Tablo 3).

Korelasyon analizlerinde ürik asit düzeyleri $\mathrm{AHI}$ ile korele bulundu. ODi, oksijen satürasyonunun \%90'ın altında ölçüldüğü süre, minimum satürasyon, ortalama satürasyon ile ürik asit düzeyi arasında korelasyon bulunmadı. Lojistik regresyon analizinde erkek cinsiyet $(p=0,003), A H I(p=0,04)$ ve hipertansiyon varlığı $(p=0,004)$ bağımsız değişkenler olarak tespit edildi.

\section{Tartışma}

Çalışmamızda, PSG ile değerlendirilen geniş bir popülasyonda serum ürik asit düzeyleri ile OUAS ilişkisi araştırılmış, ürik asit seviyelerinin OUAS olanlarda, olmayanlara göre anlamlı olarak artmış olduğu saptanmıştır. Ayrıca hastalık ağırlığı ile ürik asit düzeyleri arasında anlamlı ilişki tespit edilmiştir. Erkek hastalarda ürik asit seviyeleri kadınlara göre daha yüksek bulunmuştur. OUAS'da gece boyunca meydana gelen oksijen desatürasyon ve resatürasyonları iskemi-reperfüzyon epizodlarına benzetilebilir (7). Artmış oksidatif stres ve endotel disfonksiyonu OSAS'ta kardiyovasküler morbiditeyi arttırır. Bu durum ürik asit gibi purin metabolitlerinde ve reaktif oksijen türlerinde artış ile karakterizedir. Serum ürik asit düzeylerinde artış olmakla birlikte gut, nefropati yada nefrolitiazis gibi klinik durumların eşlik etmediği tablo asemptomatik hiperürisemi olarak adlandırıır. OUAS ile ürik asit arasındaki ilişkinin değerlendirildiği geniş popülasyonlu bir epidemiyolojik çalışmada ürik asit düzeylerinin OUAS varlığında anlamlı olarak arttığı ve AHİ, ODI, minimum $\mathrm{O}_{2}$ satürasyonu, arousal indeksi gibi, OUAS ağırlığını gösteren parametreler ile korele olduğu saptanmıştır (8).

Literatürde idrar ürik asit/kreatinin oranı ile OUAS ilişkisine dair çelişkili veriler mevcuttur. Bu ölçümün noktürnal hipokseminin belirteci olduğunu ve sürekli pozitif havayolu basıncı tedavisi ile değişiklik gösterdiğini savunan çalışmaların yanında $(7,9)$, bu verinin noktürnal hipoksemiyi ve tedavi cevabını belirlemede yaralı olmayacağını savunan görüş de mevcuttur (10). Ülkemizde yapılan bir çalışmada KOAH ve OUAS'ta ürik asit atılımı ile uykuda satürasyonun \%90'ın altında ölçüldüğü süre arasında anlamlı 
ilişki bulunmuş ve idrar ürik asit düzeyi, noktürnal hipokseminin bir belirteci olarak yorumlanmıştır. İrar ürik asit düzeyi, 5 yıllık takip sonunda, mortalite belirleyici olarak bulunmuştur (7). OUAS ve KOAH tanılı hastalarda yapılan bir çalışmada gece meydana gelen hipoksemi ile ürik asit atılımı arasında anlamlı ilişki gözlenmiş, 5 yıllık takip sonrasında başlangıçta ölçülen ürik asit seviyeleri mortalite ile ilişkili bulunmuştur (7). Ayrıca OUAS tanısı konan 40 olgunun değerlendirilerek, kontrol grubu ile karşılaştıııldığı bir çalışmada serum ürik asit seviyeleri hipoksemi ile ilişkili bulunmuştur (11).

Olgular OUAS ağırlı̆ı̆ı göre kadın/erkek olarak gruplandırıldığında, hastalığın ağırlığı arttıkça erkek/kadın oranın da arttığı görülmektedir. Normal erişkinde serum ürik asit düzeyleri erkeklerde daha yüksektir. Bu durum, premenopozal

\begin{tabular}{|c|c|c|c|c|c|}
\hline & $\begin{array}{l}\text { Kontrol } \\
n=43\end{array}$ & \begin{tabular}{|l} 
Hafif \\
$n=120$
\end{tabular} & $\begin{array}{l}\text { Orta } \\
n=124\end{array}$ & \begin{tabular}{|l|} 
Ağır \\
$\mathrm{n}=162$
\end{tabular} & $p$ \\
\hline Yaş & 41,4 & 47,2 & 51,4 & 49,8 & $<0,0001$ \\
\hline VKI & 27,7 & 30,7 & 31,7 & 32,3 & $<0,0001$ \\
\hline Uyku süresi (dk.) & 330 & 334 & 314 & 272 & $<0,0001$ \\
\hline Uyku etkinliği (\%) & 78 & 81 & 80 & 78 & 0,5 \\
\hline Uyku latansı (dk.) & 23 & 20 & 21 & 17 & 0,27 \\
\hline REM latansı (dk.) & 135 & 117 & 121 & 137 & 0,14 \\
\hline Evre 1 (\%) & 5,5 & 5,7 & 6,8 & 9,2 & $<0,0001$ \\
\hline Evre $2(\%)$ & 57 & 58 & 59,5 & 68,9 & $<0,0001$ \\
\hline Evre $3(\%)$ & 20 & 20 & 17,4 & 9,7 & $<0,0001$ \\
\hline REM (\%) & 16,5 & 16,5 & 16 & 11,8 & $<0,0001$ \\
\hline AHI & 2,4 & 10 & 21,3 & 57,8 & $<0,0001$ \\
\hline $\mathrm{Al}$ & 0,7 & 3,3 & 8,2 & 41,4 & $<0,0001$ \\
\hline $\mathrm{SpO}_{2} \% 90$ altında geçen süre & 4,2 & 7,7 & 10,2 & 28,9 & $<0,0001$ \\
\hline ODI & 1,9 & 8,4 & 17,4 & 50 & $<0,0001$ \\
\hline Minimum $\mathrm{SpO}_{2}(\%)$ & 90 & 84,5 & 83 & 76,9 & $<0,0001$ \\
\hline Ortalama $\mathrm{SpO}_{2}(\%)$ & 95 & 93,6 & 93,4 & 90,7 & $<0,0001$ \\
\hline Hemoglobin $(\mathrm{g} / \mathrm{dL})$ & 13,7 & 13,7 & 13,6 & 14 & 0,15 \\
\hline Hematokrit (\%) & 40,9 & 41 & 40,6 & 42 & 0,12 \\
\hline Lökosit & 7454 & 7789 & 7577 & 7950 & 0,39 \\
\hline Trombosit & 246666 & 245068 & 238245 & 255786 & 0,19 \\
\hline Ürik asit (mg/dL) & 5 & 5,6 & 5,9 & 6,8 & 0,02 \\
\hline Üre (mg/dL) & 31 & 33,8 & 34,6 & 33,3 & 0,47 \\
\hline Kreatinin $(\mathrm{mg} / \mathrm{dL})$ & 0,77 & 0,8 & 0,8 & 0,9 & 0,01 \\
\hline
\end{tabular}

\begin{tabular}{|c|c|c|c|}
\hline & Ürik asit düzeyi yüksek n=75 & Ürik asit düzeyi normal $n=374$ & $\mathrm{p}$ \\
\hline Yaş & $52 \pm 13$ & $48 \pm 12$ & 0,02 \\
\hline $\begin{array}{l}\text { Cinsiyet } \\
\text { Erkek \% }\end{array}$ & 77,3 & 60,4 & 0,003 \\
\hline $\mathrm{AHI}$ & 35,2 & 28,5 & 0,04 \\
\hline ODi & 31,4 & 24,1 & 0,019 \\
\hline Minimum $\mathrm{SpO}_{2} \%$ & 79,7 & 82,6 & 0,014 \\
\hline Ortalama $\mathrm{SpO}_{2} \%$ & 91,3 & 93,1 & 0,01 \\
\hline $\mathrm{SpO}_{2} \% 90$ altında geçen süre $\%$ & 23,4 & 13,1 & 0,005 \\
\hline Hipertansiyon \% & 51,4 & 29,4 & 0,001 \\
\hline
\end{tabular}


dönemdeki kadınlarda östrojenin etkisine bağlı olarak renal tübüler ürik asit reabsorbsiyonunun azalmış ve klirensinin artmış oluşuna bağlanmaktadır. Dolayısıyla, doğurgan yaştaki kadınlarda renal ürik asit atılımı daha fazladır. Menopoz sonrası dönemde ise serum ürik asiti kadınlarla erkelerde benzer seviyelerdedir (12). Kadın ve erkek OUAS ayrı ayrı değerlendirildiği çalışmalarda OUAS varlığında serum ürik asit seviyelerinin her iki cinsiyette de artmış olduğu gözlenmiştir $(13,14)$. Bizim verilerimiz de doğurgan dönemdeki kadınlarda ürik asit seviyelerinin erkelere göre daha düşük olduğunu, menopoz sonrası dönemde ise erkeklerdekine benze seviyelere ulaştığını göstermektedir.

Çalışmamızda kardiyovasküler hastalıklar, dislipidemi, hipertansiyon obstrüktif akciğer hastalıkları ile ürik asit düzeyleri arasında anlamlı ilişki gözlemedik. Bu durum adı geçen patolojilerin az sayıda hastada var olması ile ilişkili olabilir. OUAS ile kardiyovasküler hastalıklar birlikteliği bilinmektedir $(15,16)$. Bu klinik durumların ileri yaş, obezite, sigara içimi, dislipidemi gibi ortak risk faktörleri mevcuttur. Oksidatif stres ve endotel disfonksiyonu altta yatan ortak mekanizmalar arasındadır. Ürik asit ve reaktif oksijen türlerinde artış görülür. Hiperüriseminin kardiyovasküler morbidite ve mortalite için risk faktörü olduğu bilinmektedir (17). OUAS tanısı alan 67 hastanın ekokardiyografik olarak değerlendirildiği bir çalışmada sağ atriyum boyutları ile ürik asit seviyeleri arasında korelasyon bulunmuş, buna bağlı olarak, ürik asit, OUAS'da sağ kalp patolojilerinin erken belirteçleri arasında sıralanmıştır (18).

Et, deniz ürünleri ve alkol tüketiminin ürik asit düzeylerini arttırdığı bilinmektedir (19). Çalışma protokolüne kronik alkol tüketimi olan ve işlem günü alkol kullanan olgular alınmamış olmakla beraber, diğer besin maddelerinin etkileri konusunda net bilgi verememekteyiz. Bu durum çalışmanın bir limitasyonu olarak değerlendirilebilir. Ayrıca OUAS'lı hastalarda erkek cinsiyet ve hipertansiyon oranının daha yüksek olmasının ve kontrol grubunun hasta popülasyona göre daha az sayıda olgu içermesinin sonuçları etkilemiş olabilir.

\section{Sonuç}

Hiperürisemi, OUAS'da normal popülasyona göre daha sık görülür. Hastalığın ağırlığı arttıkça ürik asit seviyeleri anlamlı olarak artmaktadır. Ürik asit ile artmış reaktif oksijen türleri üretimi arasındaki bağlantı düşünüldüğünde, güncel çalışma OUAS-kardiyovasküler ilişkisine de ışık tutabilir.

Etik

Hasta Onayı: Alınmıştır.

Hakem Değerlendirmesi: Editörler kurulu tarafından değerlendirilmiştir.

\section{Yazarlık Katkıları}

Cerrahi ve Medikal Uygulama: Elif Torun Parmaksız, Banu Salepçi, Gülten Aktın Güngör, Sevda Cömert, Ergün Parmaksız, Konsept: Elif Torun Parmaksız, Dizayn: Elif Torun Parmaksız, Ergün Parmaksız, Veri Toplama veya İşleme: Elif Torun Parmaksız, Banu Salepçi, Gülten Aktın Güngör, Analiz veya Yorumlama: Elif Torun Parmaksız, Banu Salepçi, Ergün Parmaksız, Literatür Arama: Elif Torun Parmaksız, Sevda Cömert, Yazan: Elif Torun Parmaksız.
Çıkar Çatışması: Yazarlar tarafından çıkar çatışması bildirilmemiştir.

Finansal Destek: Yazarlar tarafından finansal destek almadıkları bildirilmiştir.

\section{Kaynaklar}

1. Cofta S, Wysocka E, Piorunek T, Rzymkowska M, Batura-Gabryel H, Torlinski L. Oxidative stress markers in the blood of persons with different stages of obstructive sleep apnea syndrome. J Physiol Pharmacol 2008;59:183-90.

2. Kivity S, Kopel E, Maor E, Abu-Bachar F, Segev S, Sidi Y, Olchovsky D. Association of serum uric acid and cardiovascular disease in healthy adults. Am J Cardiol 2013;111:1146-51.

3. Kuo CF, See LC, Yu KH, Chou IJ, Chiou MJ, Luo SF. Significance of serum uric acid levels on the risk of all-cause and cardiovascular mortality. Rheumatology (Oxford) 2013;52:127-34.

4. Niskanen LK, Laaksonen DE, Nyyssönen K, Alfthan G, Lakka HM, Lakka TA, Salonen JT. Uric acid level as a risk factor for cardiovascular and all-cause mortality in middle-aged men: a prospective cohort study. Arch Intern Med 2004;164:1546-51.

5. Rechtschaffen A, Kales A. A manual of standardized terminology, techniques and scoring system for sleep satges in human subjects. CA: Brain Information Service, Los Angeles, UCLA, 1968.

6. Berry RB, Brooks R, Gamaldo CE, Harding SM, Marcus CL and Vaughn BV for the American Academy of Sleep Medicine. The AASM Manual for the Scoring of Sleep and Associated Events: Rules, Terminology and Technical Specifications, Version 2.0. www.aasmnet.org, Darien, Illinois: American Academy of Sleep Medicine, 2012.

7. Ozanturk E, Ucar ZZ, Varol Y, Koca H, Demir AU, Kalenci D, Halilcolar $\mathrm{H}$, Ozacar R. Urinary uric acid excretion as an indicator of severe hypoxia and mortality in patients with obstructive sleep apnea and chronic obstructive pulmonary disease. Rev Port Pneumol (2006) 2016;22:18-26.

8. Hirotsu C, Tufik S, Guindalini C, Mazzotti DR, Bittencourt LR, Andersen ML. Association between uric acid levels and obstructive sleep apnea syndrome in a largeepidemiological sample. PLoS One 2013;24;8:e66891.

9. Braghiroli $A$, Sacco C, Erbetta M, Ruga V, Donner CF. Overnight urinary uric acid: creatinine ratio for detection of sleep hypoxemia. Validationstudy in chronic obstructive pulmonary disease and obstructive sleep apnea before and after treatment with nasal continuous positive airway pressure. Am Rev Respir Dis 1993; 148:173-8.

10. McKeon JL, Saunders NA, Murree-Allen K, Olson LG, Gyulay S, Dickeson J, Houghton A, Wlodarczyk J, Hensley MJ. Urinary uric acid:creatinine ratio, serum erythropoietin, and blood 2,3diphosphoglycerate in patients with obstructive sleep apnea. Am Rev Respir Dis 1990;142:8-13.

11. Hira HS, Shukla A, Kaur A, Kapoor S. Serum uric acid and lactate levels among patients with obstructive sleep apnea syndrome: which is a better marker of hypoxemia? Ann Saudi Med 2012;32:37-42.

12. Antón FM, Garcia Puig J, Ramos T, González P, Ordas J. Sex differences in uric acid metabolism in adults: evidence for a lack of influence of estradiol-17 beta (E2) on the renal handling of urate. Metabolism 1986;35:343-8.

13. Pływaczewski R, Bednarek M, Jonczak L, Górecka D, Sliwinski P. Hyperuricaemia in females with obstructive sleep apnoea. Pneumonol Alergol Pol 2006;74:159-65.

14. Plywaczewski R, Bednarek M, Jonczak L, Gorecka D, Sliwińiski P. Hyperuricaemia in males with obstructive sleep apnoea (OSA). Pneumonol Alergol Pol 2005;73:254-9.

15. Vijayan VK. Morbidities associated with obstructive sleep apnea. Expert Rev Respir Med 2012;6:557-66.

16. Anker SD, Doehner W, Rauchhaus M, Sharma R, Francis D, Knosalla C, Davos CH, Cicoira M, Shamim W, Kemp M, Segal R, Osterziel KJ, 
Leyva F, Hetzer R, Ponikowski P, Coats AJ. (2003) Uric acid and survival in chronic heart failure: validation and application in metabolic, functional, and hemodynamic staging. Circulation 2003;107:1991-7.

17. Fang J, Alderman MH. Serum uric acid and cardiovascular mortality the NHANES I epidemiologic follow-up study, 1971-1992. National Health and Nutrition Examination Survey. Jama 2000;283:2404-10.
18. Araz Ö, Yilmazel Uçar E, Değırmencı H, Pulur D, Acemoğlu H, Bayram $E$, Gündoğdu F, Akgün M. The correlation of ECHO findings of right cardiac pathologies with BNP, uric acid, and CRP in OSAS. Turk J Med Sci 2014;44:832-8.

19. Schlesinger N. Dietary factors and hyperuricaemia. Curr Pharm Des 2005; 11:4133-8. 